\title{
nature
}

heard says the government knows what to do to solve the problems of the North of England," said political scientist Anand Menon, director of the UK in a Changing Europe research programme.

The government needs to listen to these warnings if it is to make good on its promises. As the prime minister and his senior advisers start to make decisions in the coming months, leaders of the research community must continue to use their influential voice and ensure that UK researchers are generously funded, that underserved communities do not lose out and that research policies continue to reflect an international consensus.

\section{Dahrendorf's wish}

"The European Union is seen by many as a model. And Britain must be part of that model." The German-British philosopher Ralf Dahrendorf wrote these words in frustration in 1995 when a previous Conservative UK government found itself in turmoil over Britain's relationship with the EU.

Dahrendorf was unusually placed in that he could see Britain's relationship with the EU from many sides. He could see how EU membership was being interpreted by some as a loss of sovereignty in a post-imperial nation. But as a refugee from Nazi Germany who had been welcomed by Britain, he also understood the EU's crucial importance as the backstop against a return to authoritarianism in continental Europe.

Dahrendorf's wish will be denied. But it is essential that both the United Kingdom and the remaining $27 \mathrm{EU}$ member states and EU institutions do not let Brexit diminish that mission. The EU exists to protect democracy and the rule of law. It ensures continued peace and prosperity through negotiation and compromise, through the freedom to travel and trade, and by the strong helping the weak - all catalysed by knowledge, research and innovation. These are values to which every nation must aspire, including the United Kingdom even if it is no longer part of the EU.

\section{What you want}

\section{Nature to do next}

\author{
We asked readers what we should \\ focus on in the next decade. Here is what \\ you said.
}

ate last year, as Nature marked its 150th anniversary, we spent time reflecting on our values and how we could improve. We were keen to hear from you, our readers, so we put up a survey that asked: "What activity do you think is most important for Nature to focus on over the next decade?"
More than 500 of you responded (thank you!) and four things stood out. You would like Nature to make papers and data easier to access; help readers to find and digest research more easily; work to improve research integrity; and publish and communicate research that addresses global challenges. These responses and the many additional comments you sent will guide us as we chart a course into the new decade.

Some readers urged us to improve accessibility in its broadest sense. We should make research "easier for very curious but non specialized people to read", wrote one. We strive to ensure that abstracts to research articles and all our news and opinion content are clear and engaging for readers from different fields and at different career stages. But it's important to be reminded, as another reader told us, that palaeontology should be accessible to a neuroscientist and vice versa. It's equally important, as a reader from Mexico said, that we maintain "truthfulness and impartiality in the global dissemination of science".

We're pleased that many readers complimented Nature's daily Briefing, our round-up of essential reading in research news from across the world. We want to do more to help readers make sense of what can be an overwhelming volume of information about new research.

Respondents also urged us to do more to make science open by further embracing open access, open data and reproducibility - including publishing peer-reviewed work that reproduces the results of previous studies. These views are informing our direction. And quite a few readers asked why Nature covers policy and politics in science; we see this as an essential part of what we do because policy decisions affect research and researchers' lives, and because the outcome of research affects policy decisions, too.

We're delighted to see so many readers urge us to focus on global challenges. You're right. Nature is committed to publishing and reporting in the areas that fall under the United Nations Sustainable Development Goals, and 2020 will be a busy year. In October, countries that belong to the UN Convention on Biological Diversity will meet in Kunming, China, to update global goals to reduce biodiversity loss. The following month, world leaders will gather in Glasgow, UK, to agree on a new and hopefully more ambitious set of climate targets. Before that, in June, representatives of many nations will convene in Lisbon with scientists, businesses and campaign groups for the UN Oceans Conference. We'll be covering all of these events.

You also told us in our poll that we should focus on increasing the diversity of our authors and contributors. We are redoubling our efforts here - and also reiterate our commitment from last December to having no more male-only speaker panels and organizing committees for Nature events. At the same time, we fully recognize that there is much more that we need to do.

Science, as one reader reminds us, is an essential part of humanity's heritage. “I hope that Nature can keep improving, and make [an] effort to preserve and select important information in a way that future generations can access them easily."

We very much agree. 